Тернопільський національний медичний університет імені І. Я. Горбачевського МОЗ Украӥни

\title{
ВИКОРИСТАННЯ ІНТЕРАКТИВНИХ МЕТОДІВ ВИКЛАДАННЯ ТА РОЗВИТОК ДИСТАНЦІЙНОЇ ОСВІТИ ЛІКАРІВ У ТЕРНОПІЛЬСЬКОМУ НАЦІОНАЛЬНОМУ МЕДИЧНОМУ УНІВЕРСИТЕТІ ІМЕНІ І. Я. ГОРБАЧЕВСБКОГО МОЗ УКРАЇНИ В УМОВАХ КАРАНТИНУ
}

\author{
L. Ya. Posolenyk, O. Ya. Vydoinyk \\ I. Horbachevsky Ternopil National Medical University

\section{USE OF INTERACTIVE METHODS OF TEACHING AND DEVELOPMENT OF DISTANCE EDUCATION OF DOCTORS IN I. HORBACHEVSKY TERNOPIL NATIONAL MEDICAL UNIVERSITY IN QUARANTINE CONDITIONS}

\begin{abstract}
Анотація. У статті висвітлено досвід використання освітніх платформ навчання Moodle та Microsoft Teams для проведення практичного онлайн-заняття й оцінено ефективність інтерактивної інноваційної технології «круглий стіл» у формуванні професійних та комунікативних компетентностей у майбутніх медичних працівників у ТНМУ імені І. Я. Горбачевського МОЗ України.

Дистанційне навчання у ТНМУ імені I. Я. Горбачевського МОЗ України через освітню дистанційну платформу Microsoft Teams на сьогодні є складовою освітнього процесу й забезпечує навчання у найбільш зручному місці та часі, надає доступ до електронних баз знань. Інтерактивна технологія навчання - це така організація навчального процесу, за якої неможлива неучасть студента в колективному взаємодоповнювальному, заснованому на взаємодії всіх його учасників процесі навчання, зокрема й під час вимушеного, внаслідок карантину. При цьому такі форма і засоби навчання вимагають від викладача вдосконалення викладання як за змістом, так і за його формою й оволодіння сучасними засобами та методами навчання i, водночас, забезпечують виконання навчального навантаження.

Ефективне поєднання інтерактивних методів навчання та систем електронних освітніх платформ протягом дистанційного навчання дозволяє забезпечити максимальне здобуття студентом практичних знань й умінь, розвинути його комунікативні компетентності, забезпечує високий рівень клінічного мислення, полегшить поєднання теоретичних знань 3 практичною діяльністю після закінчення карантинних обмежень і може бути рекомендованим для широкого впровадження в навчальний процес у закладах вищої освіти та безперервного професійного розвитку лікарів через запровадження доступних слухачам освітніх платформ із широким використанням наявних WEB-ресурсів.
\end{abstract}

Ключові слова: інтерактивні методи навчання; дистанційна освіта; освітня платформа; карантин.

Abstract. The article highlights the experience of using educational training platforms Moodle and Microsoft Teams for practical online classes and evaluates the effectiveness of interactive innovative technology "round table" in the formation of professional and communicative competencies of future medical workers at I. Horbachevsky Ternopil National Medical University.

Distance learning at I. Horbachevsky Ternopil National Medical University through the educational distance platform Microsoft Teams today is a part of the educational process and provides training in the most convenient place and time, provides access to electronic knowledge bases. Interactive learning technology is an organization of the educational process in which it is impossible for a student not to participate in a collective complementary, based on the interaction of all its participants learning process, including during the forced, due to quarantine. At the same time, such forms and means of teaching require the teacher to improve teaching both in content and form and to master modern means and methods of teaching and, at the same time, ensure the implementation of the teaching load.

Effective combination of interactive teaching methods and systems of electronic educational platforms during distance learning allows to ensure maximum acquisition of practical knowledge and skills by students, to develop their communicative competencies, provides a high level of clinical thinking and facilitates combination of theoretical knowledge with practical activities after quarantine restrictions

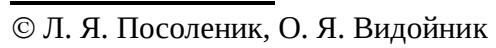


wide introduction into the educational process in higher education institutions and continuous professional development of doctors through the introduction of educational platforms available to students with extensive use of available WEB-resources.

Key words: interactive teaching methods; distance education; educational platform; quarantine.

Вступ. Поширення коронавірусної інфекції COVID-19 у світі та Україні обумовило активні пошуки шляхів удосконалення педагогічних технологій підготовки фахівців охорони здоров’я, зорієнтованих на формування широкої професійної компетентності, розвиток творчих і потенційних можливостей, забезпечення ефективних умов для самоосвіти та самовиховання студента [5, 7]. Переведення науково-педагогічних працівників ТНМУ імені І. Я. Горбачевського МОЗ України на дистанційний режим роботи відбулося відповідно до наказу МОН України від 16.03.2020 р. № 430 щодо попередження поширення коронавірусної інфекції [6]. Ним передбачено виконання освітніх програм закладів освіти, зокрема шляхом організації освітнього процесу із використанням технологій дистанційного навчання, що не передбачає відвідування закладів освіти ії здобувачами, а також виконання працівниками закладів освіти іншої роботи (організаційно-педагогічної, методичної, наукової тощо).

У сучасних умовах дистанційне навчання активно впровадилось у навчальний процес у ВНЗ України та світу. Варто зауважити, що кафедри ТНМУ імені I. Я. Горбачевського МОЗ України були готовими до запровадження позааудиторної роботи студента завдяки активно впровадженим інтерактивним методам навчання. Ще 3 початку 2000-х років у ТНМУ імені І. Я. Горбачевського МОЗ України запроваджено застосування освітньої платформи Moodle, на якій розміщено текстові і відеоматеріали по підготовці до практичних занять, презентації та зміст лекцій і тестові завдання для самоконтролю студента, що дозволило не припиняти навчальний процес та онлайн-оцінювання успішності студентів протягом періоду карантину у березні - червні 2020 р. і забезпечувати їх безперервний професійний розвиток. Актуальними постали питання підвищення рівня комунікації між викладачем i здобувачем вищої освіти та активації і розвитку клінічного мислення студента $[1,2,8]$.

Мета статті - розвиток сучасних та доступних методів дистанційної освіти у ТНМУ імені I. Я. Горбачевського МОЗ України і вдосконалення клінічного мислення студентів із використанням інтерактивних методик навчання в умовах карантинних заходів.
Теоретична частина. Перший досвід дистанційної освіти в умовах карантинних обмежень визначив доцільність та необхідність пошуку нових освітніх платформ, які дозволять безпосередній контакт викладач - студент, що забезпечить, перш за все, допомогу студенту у засвоєнні базових знань, активізувати і мотивувати творчу роботу, набуті студентами теоретичні знання пов'язати 3 практичною діяльністю, враховуючи індивідуальні особливості та здібності кожного студента, забезпечити самостійність виконання кожним студентом поставлених завдань, розвивати клінічне мислення кожного студента, добиватися засвоєння студентами основних знань й умінь з тем дисципліни.

3 вересня 2020 р. на кафедрах ТНМУ імені I. Я. Горбачевського МОЗ України було започатковано застосування платформи Microsoft Teams. Цією програмою можуть користуватись усі учасники навчального процесу, які $є$ зареєстровані у Google, як на персональному комп'ютері, так і у мобільному форматі, що дає можливість викладачу та студенту входити у навчальний процес за допомогою смартфона. Це є більш ефективним і правильним, ніж просто спілкування у Viber-групах чи через електронну пошту, де важко завантажити великий відеоматеріал щодо клінічного випадку тощо. Спілкуючись за допомогою смартфона, технічно це може бути простіше й доступніше i для викладачів, і для слухачів. Викладач кафедри започатковує свою освітню кімнату, у якій, за допомогою календаря, планує свої практичні заняття і лекції на певний період часу (день, тиждень, місяць), запрошує групу студентів (практичне заняття) чи декілька груп (лекція) по номеру групи або індивідуально за ПІБ кожного студента у цій же програмі. Система Microsoft Teams автоматично одразу інформує усіх членів наради про запланований захід, який регламентується заданим викладачем часом проведення заняття згідно з чинним розкладом. Система самостійно повідомляє про час початку запланованої наради (практичне заняття, лекція) аудіосигналом, що є додатковою зручністю.

Процес освіти лікарів має бути безперервним, і завдання кожного викладацького колективу знайти ті інструменти, що забезпечать неперервність навчального процесу, покращити якість практичної 
підготовки та клінічного мислення студентів із використанням інтерактивних методик та подальшим закріпленням в умовах клініки після закінчення періоду карантину [4].

Визначений кафедрою матеріал (презентації, аудіофайли, навчальні фільми до теми, посилання на корисні освітні ресурси та інші навчально-методичні матеріали) викладач вільно викладає під час проведення віртуального заняття за конкретною темою та дає поточні завдання слухачам. Це дозволяє забезпечити необхідний рівень підготовленості студентів, проводити систематичне оцінювання їх знань та поточні дискусії щодо тих чи інших питань у процесі освоєння навчального матеріалу. Такий формат відповідає власне аудиторній роботі педагога та студента.

Стратегія розвитку інтерактивного навчання бачить насамперед студента в ролі активного учасника освітнього процесу. Для оцінки вхідного рівня знань студентів заняття розпочинається 3 проведення короткого усного опитування та обговорення теми заняття. У подальшому - перегляд відеоматеріалів та розбір клінічних випадків. Для успішного перебігу навчального процесу необхідно створювати ситуації «відкритого зіткнення власних сумнівів і протиріч із сумнівами й протиріччями інших». Важливо, аби ці протиріччя виникали як у діалозі між викладачем і студентами, так і між самими студентами, з урахуванням їхніх інтересів, думок, поглядів і позицій. Тому заняття проводиться викладачем за однією із методик інтерактивного навчання, а саме: за методикою «Круглий стіл» [3, 9]. Розвиток умінь брати участь у колективному обговоренні, дискутувати, висловлюватися, ставити запитання (особливо зараз в умовах ізольованого самостійного опрацювання матеріалу студентами за період карантинних обмежень) сприяє розвитку і вдосконаленню клінічного мислення у студента та бажання вчитися й разом із викладачем розв'язувати проблеми, що виникли.

Викладач розпочинає «круглий стіл» і визначає його функції (колективна дискусія, обговорення актуальної проблеми, пошук конкретного рішення проблеми тощо). Під час обговорення викладач послідовно надає слово кожному з бажаючих студентів, заохочуючи тих, хто мовчить. Викладач проводить зі студентами обговорення того, що відбулося (прийом пацієнта, вибір оптимального методу лікування, розбір особливостей постановки діагнозу та ін.), їхніх вражень і думок. Беручи участь у дискусіях, обговорюючи різні проблеми, імітуючи ситуації на занятті, студент засвоює від 70 до 90 \% інформації, розвиває індивідуальні творчі здібності, навчається правильно реагувати, самостійно оцінювати і вирішувати критичні ситуаційні задачі та розвиває комунікативні навички. Викладач підбиває підсумки та узагальнює опрацьовану інформацію. Підсумковий контроль знань студентів проводиться за допомогою дистанційних освітніх технологій за допомогою діючої уже і виправданої на даний час платформи Moodle. Також необхідно інформувати студентів про можливості використання для самоосвіти відео- та інших навчальних матеріалів за визначеною темою, що є у відкритому доступі, зокрема навчальні бази провідних закладів медичної освіти.

Дистанційне навчання у ТНМУ імені І. Я. Горбачевського МOЗ України через освітню дистанційну платформу Microsoft Teams на сьогодні є складовою освітнього процесу, маючи при цьому низку переваг. Воно забезпечує навчання у найбільш зручному місці та часі, надає доступ до електронних баз знань. Плюс інтерактивна технологія навчання - це така організація навчального процесу, за якої неможлива неучасть студента в колективному взаємодоповнювальному, заснованому на взаємодії всіх його учасників процесі навчання, зокрема й під час вимушеного, внаслідок карантину. При цьому такі форма і засоби навчання вимагають від викладача вдосконалення викладання як за змістом, так і за його формою й оволодіння сучасними засобами та методами навчання i, водночас, забезпечують виконання навчального навантаження.

Отже, враховуючи тривалість карантинних заходів та в умовах дистанційного навчання, застосування різноманітних форм інтерактивної позааудиторної роботи педагогів та здобувачів вищої медичної освіти у ТНМУ імені І. Я. Горбачевського MO3 України забезпечує достатній рівень підготовки студента, враховує особистісні якості студентів, передбачає творчий характер розв'язання професійних педагогічних проблем.

Висновки та перспективи подальших досліджень. Інтеграція платформи Microsoft Teams для дистанційної форми організації навчального процесу дозволила оптимізувати процес переходу 3 класичної форми навчання до дистанційної. Ефективне поєднання інтерактивних методів навчання та систем електронних освітніх платформ протягом дистанційного навчання дозволяє забезпечити максимальне здобуття студентом практичних знань й умінь, розвинути його комунікативні компетент- 
ності, забезпечує високий рівень клінічного мислення, полегшить поєднання теоретичних знань 3 практичною діяльністю після закінчення карантинних обмежень і дозволяє зробити висновок, що комунікативна компетентність $€$ необхідною умовою ефективного виконання лікарем свого професійного обов’язку. Отриманий досвід надає оптимізму щодо впровадження інноваційних форм навчання для медико-біологічних дисциплін.

Імплементація сучасних та доступних методів дистанційної освіти і вдосконалення клінічного мислення фахівців із використанням інтерактивних

\section{Список літератури}

1. Власенко О. М. Використання інтерактивних методів навчання у сучасній вищій школі / О. М. Власенко // Вісник Житомирського державного університету. - 2012. - № 64. - С. 94-97.

2. Інтерактивні технології навчально-пізнавальної діяльності - інноваційні методики змішаного навчання / Т. О. Перцева, Л. І. Конопкіна, Т. В. Кіреєва [та ін.] // Медична освіта. - 2018. - № 4. - С. 73-76.

3. Пометун О. І. Енциклопедія інтерактивного навчання / О. І. Пометун. - К., 2007. - 144 с.

4. Пометун О. I. Сучасний урок. Інтерактивні технології навчання : наук.-метод. посіб. / О. І. Пометун, Л. В. Пироженко. - К. : Видавництво А.С.К., 2004. 192 c.

\section{References}

1. Vlasenko, O.M. (2012). Vykorystannia interaktyvnykh metodiv navchannia u suchasnii vyshchii shkoli [The use of interactive teaching methods in modern higher education]. Visnyk Zhytomyrskoho derzh un-tu - Bulletin of Zhytomyr State University, 64, 94-97 [in Ukrainian].

2. Pertseva, T.O., Konopkina, L.I., \& Kireeva, T.V. (2018). Interaktyvni tekhnolohii navchalno-piznavalnoi diialnostiinnovatsiini metodyky zmishanoho navchannia [Interactive technologies of educational and cognitive activity innovative methods of blended learning]. Medychna osvita Medical Education, 4, 73-76 [in Ukrainian].

3. Pometun, O.I. (2007). Entsyklopediia interaktyvnoho navchannia [Encyclopedia of interactive learning]. Kyiv [in Ukrainian].

4. Pometun, O.I., \& Pyrozhenko, L.V. (2004). Suchasnyi urok. Interaktyvni tekhnolohii navchannia: nauk.-metod. Posib [A modern lesson. Interactive learning technologies: Guidelines]. Kyiv: Vydavnytstvo A.S.K. [in Ukrainian].

5. Pro zapobihannia poshyrenniu na terytorii Ukrainy koronavirusu COVID-19 [On prevention of the spread методик навчання шляхом застосування освітніх платформ та використанням наявних світових загальнодоступних WEB-ресурсів може і має бути рекомендованою для широкого впровадження в навчальний процес у закладах вищої освіти та безперервного професійного розвитку лікарів. Представлені дані $є$ початковою ланкою характеристик ефективності та доцільності проведення практичних онлайн-занять в умовах дистанційного навчання і потребують подальшого детального, глибокого, диференційованого вивчення та аналізу.

5. Про запобігання поширенню на території України коронавірусу COVID-19 : Постанова Кабінету Міністрів України від 11.03.2020 р. № 211.

6. Про затвердження Положення про дистанційне навчання : наказ Міністерства освіти і науки України від 25.04.2013 р. № 466.

7. Про організаційні заходи для запобігання поширенню коронавірусу COVID-19 : наказ Міністерства освіти і науки України від 16.03.2020 р. № 406.

8. Семенова А. В. Розвиток професійної компетентності фахівців засобами парадигмального моделювання (інтерактивний тренінг) : навч.-метод. посіб. / А. В. Семенова. - Одеса : СВД Черкасов М. П., 2006. - 130 с.

9. Шербань П. М. Навчально-педагогічні ігри у вищих навчальних закладах : навч. посіб. / П. М. Щербань. К. : Вища школа, 2004. - 207 с.

of coronavirus COVID-19 on the territory of Ukraine]. Postanova Kabinetu Ministriv Ukrainy vid 11 bereznia 2020 r. No 211 - Resolution of the Cabinet of Ministers of Ukraine of March 11, 2020 No. 211 [in Ukrainian].

6. Pro zatverdzhennia Polozhennia pro dystantsiine navchannia [On approval of the Regulations on distance learning]. Nakaz Ministerstva osvity i nauky Ukrainy vid 25.04.2013 r. No 466 - Order of the Ministry of Education and Science of Ukraine of April 25, 2013 No. 466 [in Ukrainian].

7. Pro orhanizatsiini zakhody dlia zapobihannia poshyrenniu koronavirusu COVID-19 [About organizational measures to prevent the spread of coronavirus COVID-19]. Nakaz Ministerstva osvity i nauky Ukrainy vid 16.03.2020 r. No 406 - Order of the Ministry of Education and Science of Ukraine of March 16, 2020 No. 406 [in Ukrainian].

8. Semenova, A.V. (2006). Rozvytok profesiinoi kompetentnosti fakhivtsiv zasobamy paradyhmalnoho modeliuvannia (interaktyvnyi treninh): navch.-metod. posib. [Development of professional competence of specialists by 
means of paradigmatic modeling (interactive training): teaching method. way]. Odesa: SVD Cherkasov, M.P. [in Ukrainian].
9. Shcherban, P.M. (2004). Navchalno-pedahohichni ihry u vyshchykh navchalnykh zakladakh: navch. posib [Educational and pedagogical games in higher educational institutions: Textbook]. Kyiv: Vyshcha shkola [in Ukrainian].

Отримано 12.11.20

Рекомендовано 16.11.20

Електронна адреса для листування: posolenykly@tdmu.edu.ua 